\title{
The Educational Tourism (Edutourism) Development Through Community Empowerment Based on Local Wisdom and Food Security
}

\author{
Adhi Iman Sulaiman ${ }^{1}$, Chusmeru $^{1} \&$ Bambang Kuncoro ${ }^{2}$ \\ ${ }^{1}$ Department of Communication Science, Jenderal Soedirman University, Indonesia \\ ${ }^{2}$ Department of Political Science, Jenderal Soedirman University, Indonesia \\ Correspondence: Adhi Iman Sulaiman, Kampus Grendeng, Purwokert, Central Java 53122, Indonesia. Tel: 62- \\ 8163-529-4. E-mail: adhi.2005unsoed@gmail.com
}

Received: July 21, 2019; Accepted: August 3, 2019; Published: August 6, 2019

\begin{abstract}
Rural areas that have food security and local wisdom are the main capital to develop agro-tourism areas that can improve the welfare and independence of the community. The research aim to analyze educational tourism (edutourism) development through community empowerment based on local wisdom and food security. The research used Participatory Learning and Action (PLA) methode, informant were determined purposively consisting of farmers group, business group, management of agrotourism and the village officials. Data were collected by interview, observation, discussion and Participatory Decision Making (PDM). Research sites in Wonoharjo village, Rowokele subdistrict, Kebumen regency and Serang village, Karangreja subdistrict, Purbalingga regency in Central Java of Indonesia. Data analysis used community development analysis. The results showed (1) The Wonoharjo village and Serang village has the potential and advantages as the area of agrotourism based on food security of horticulture and can be used as an edutourism and many tourists visit for educational activities, training, empowerment programs, research, study of the laboratory and college programs. (2) Empowerment program should be make tourism locations for education, training and work practices processing of agricultural, food security, local wisdom, creating caring and nature conservation for all groups ranging from elementary school children to college, private institutions, and social institutions.
\end{abstract}

Keywords: agrotourism, community empowerment, edutourism, food security, local wisdom

\section{Introduction}

The dynamics of development may not be separated from the interrelated problems, such as the increasing population, unemployment, poverty, productivity of import-dependence basic commodities and malnutrition which result in difficulties to fulfill the daily needs due to the basic commodities' higher prices. The other causes of large-scale industrialization impacts which is not in accordance with the analytical results of environmental impacts are the occurring inappropriate land transfers, environmental pollutions such as air pollution and chemical wastes, and no support on agricultural sectors due to the lessening agricultural lands, decreasing youth interests on agricultural sectors, and the threatened food security as the people's basic needs. Basundoro (2001, 133) states industry may result in various impacts on human life, both social and nonsocial changes, such as city physical changes and environmental pollution. Furthermore, unemployment, low productivity, lessening productive lands, weakening product marketing and strong imports may also take place. Irianta $(2008,131)$ states that industrial impacts cover road damage, drying water sources, traffic jams, wastes, air pollution, and inappropriate land transfers. Fakhrian et al. $(2015,15)$ explain that industrial activities may result in the increasing pollutions of water, air and land, yet no environmental prevention to face pollution.

Those problematic issues become important notes in consideration of Law No. 41 of 2009 on Sustainable Agricultural Land Protection that the increasing population growth, economic, and industrial development result in agricultural land degradation, transfer, and fragmentation have threatened the supporting capacity of national territory in maintaining food independence, resilience, and sovereignty. Furthermore, in part of the explanation mentioning that threat for food security encourages Indonesia to frequently import food products to meet its people's needs. The increasing number of population, threats directed to food production may result in food insecurity in the future that Indonesia requires additional food supplies and cultivation lands. 
According to Saptana and Ashari $(2007,123)$, problems in food security are due to the decreasing land fertility and productivity as well as the reducing environmental support, widely spreading critical land, increasing pollution, environmental damages and increasing number of poor and unemployed people in rural areas.

Thus, in the development of one most important area is to overcome the problem of food security in response to the basic and fundamental needs concerning on people's daily life. According to the Law of the Republic of Indonesia Number 18 of 2012 on Food, the point is that food security is the ability to provide adequate food needs from its quantity, quality, guaranteed availability, affordable prices, nutrition and variety, and equally, equitably and sustainably towards food self-sufficiency

Indonesia, as a country it have diverse natural resources, with a large population and food sources, should be able to meet the needs of food sovereignty and reliance. According to the Ministry of National Development Planning Agency in 2013-2014, the strategic development issues on stabilizing food production for the sustainability of food security and development priorities to reduce poverty and strengthen food security have been positioned in the first place. The report made by the Food Security Agency of the Ministry of Agriculture in 2016, explains that food security is one main priority in the National Development Plan of 2015-2019 which focused on increasing food availability, strengthening food distribution, accelerating food diversification, and monitoring fresh food security. The aim is to increase economic growth and reduce poverty as the realization of social, cultural and economic development as part of overall development. The outcomes resulted from the priority activities of Food Security Agency in 2015 are (1) Development of sustainable food house area in the village (77.96\%); (2) Strengthening the community food distribution institutions, such as farmer groups (87.99\%); (3) Community food barns (95.30\%); and (4) Food reliance areas (88.54\%).

There are several problems related to food security. Purwaningsih $(2008,2)$ states that the needs on food continuously increase along with the increasing population. From the fulfillment point of view, not all needs on food may be fulfilled since the production capacity and food distribution are highly limited and nationally lead to food instability between the needs and fulfillment. Saliem $(2011,2)$ states that the Indonesia has many potential agricultural resources, but the population is still unable to fulfill their nutrition, so there must be an increase in food security and family nutrition by means of families able to use the land for cultivation of vegetables and fruits. Ashari et al. $(2012,13)$ states that problem of house yard utilization program is that it has not been intensively recognized and is still as a secondary job, not market-oriented, lack of specific technology for yard utilization and insufficient mentoring processes given by the officers.

Based on the reports made by Ministry of Agriculture in 2016-2017 about food security, it is stated that various resource potentials, including natural, human, cultural, technological or financial resources are not optimally utilized to improve food availability, food insecurity handling, food accessibility, development of food distribution system, stabilization of food prices and food reserves; as well as development of the diversified, nutritionally balanced, and safe food consumption.

Problems of food security may be overcome by implementing the community empowerment program, potential development, and prosperity improvement of the communities, especially at the village level. According to Sukandar $(2004,165)$, malnutrition in rural and urban communities impacts on the decline of human resource quality and productivity that strengthening food security from the household level is highly required. Sulaiman et al. $(2016,233)$ states that village development determines the success of regional and national development since a village has various resources to meet the people's needs, such as the yields resulted from agricultures, plantations, livestock, fisheries, and tourisms.

The villages can maintain their food security potentials with the community empowerment programs to meet basic needs and be a superior commodity as the income sources and people's welfare. Thus, the villages no longer become the object of development, abandoned by their communities since becoming urbanization sources and burden of urban development. Community empowerment is conducted in participatory, meaning that activities must be comprehensive and sustainable from the planning of programs, implementation, monitoring and evaluation of development involve the villager communities. Mardikanto and Soebiato $(2012,115)$ state that empowerment aims to facilitate the community to become the main actors in utilizing economic, social, production and ecological resources in a sustainable manner.

The Government should then become more pro-active in communicating the participatory and cooperative development by openly and harmoniously making the meeting agenda or dialogue with the community members (Handoko et al., 2014, 151). The procedures in sustainable development are utilized as the social and ecological system to provide the efforts in creating a vision and networks in realizing a vision for the strategic development and implementation in various sectors, monitoring and evaluation (Telesford \& Strachan, 2017, 35). 
In sustainable development it is important to make integrated community sustainability planning by involving all parties to make policies (Collins, et al., 2017: 124). Based on the results of several studies, that are useful for determining similarities and differences to determine similarities, differences, novelty, and state of the art in research. So that is very important and strategic to conduct a study on food security, especially at the local level, such as villages to support the development of the surrounding areas and in the cities whether resulted from the agriculture, plantation, livestock, enforcement supply, and tourism. This paper aims at creating a model of community entrepreneurship development based on local wisdom and food security for agrotourism development in Serang village, of Purbalingga regency as the recipient of the best national level award for local food security in 2013-2014 and Wonoharjo village, Rowokele subdistrict of Kebumen regency is the first winner for the independent of food security village in Central Java Province in 2018. Pamulardi $(2006,84)$ states that agrotourism with a concept of environmental insight on conservation of natural resources and environment has a mutual relationship. Novitasari (2014: 2) states that agro-tourism is developing the cultural and agricultural potentials as well as the tourist areas and festival activities. Nugroho et al., $(2012,19)$ describes that the development of rural agro-tourism which utilizes agricultural potentials, and involves rural communities, may serve as community empowerment in accordance with the community empowerment based on tourism. This research has a unique and novelty, namely the development of potentials of horticultural, food security and local wisdom to support and make it as an agrotourism and edutourism in Serang village and Wonoharjo village of Central Java in Indonesia.

\section{Method}

The study used qualitative methode of Participatory Learning and Action to identify problems and potentials of society, to analyze, decide, and obtain deeper understanding through assessment and learning processes on situation of certain community (community worker) (Adi 2013, 283).

The informants are purposively determined, consisting of farmers group, small and medium enterprises (SMEs) group, tourism member and managers as well as Serang village government. The data are collected through interviews, Focus Group Discussion (FGD), observations, Participatory Decision Making (PDM).

The research location is in Serang village, Karangreja subdistrict in Purbalingga regency of as the recipient of the best national level award for local food security in 2013-2014 and Wonoharjo village, Rowokele subdistrict of Kebumen regency, Central Java of Indonesia is the first winner for the independent of food security village in Central Java Province in 2018.

Data analysis used community development analysis consisting of (1) identification, categorizing the problems, general and specific objectives. (2) analyzing the problems. (3) preparing the action plans, such as methods, programs, and achievement of the action. (4) Evaluating the entire processes, actions plans and control (Kenny 1999, 54).

\section{Results and Discussion}

Serang is selected to become a food security-based tourism village (Agro-tourism) officially inaugurated through the Decision Letter of Purbalingga Regent Number 413.1/180 of 2010 on the establishment village tourism of Serang village. Based on the monographic data of 2018 , Serang village has natural potentials in mountainous areas with the lowest area of 650 meters and the highest of 1650 meters above the sea level, cool weather at the lowest temperature of $160 \mathrm{C}$ and the highest of $280 \mathrm{C}$. The topographic condition covers $30 \%$ land, $45 \%$ slope, and $25 \%$ hill from the total area of $2.878,390$ hectares. The total population is 8.379 people consisting of 2.575 heads of family with the major occupational status of farmers by 3.385 people $(59.40 \%)$, private sector workers by 1.499 (26.30\%), farm workers by 509 people (8.93\%), and merchant by 231 people (4.05\%). Most village people's occupation which is up to $90 \%$ is farming, that is, planting Gogo paddy and crops; hard plants varieties, such as coffee, clove, coconut sugar, and wood plant which most of them are horticulture with the biggest commodity of strawberry in a total area of 52.4 hectares and produces 2.814 tons/year; vegetables, such as potato, tomato, big chilli, cayenne pepper, cabbage, carrot, mustard green, spring onion, celery leaves, caisim, pakcoy, land lettuce, and corn.

Whereas Wonoharjo village, Rowokele subdistrict, Kebumen regency, Central Java, based on 2018 village monograph data, Wonoharjo Village has an area of 919.7 hectares consisting of 267.7 hectares of housing, 194.3 hectares of rice fields, 451.2 hectares of plantation land; 1 ha of fisheries and 5.5 hectares of land owned by the village government. The Wonoharjo village have population of 6,460 people and at most 5,491 (85\%) residents are farmers who are members of farmer groups in agriculture, plantations especially coconut sugar, coffee and clove commodities, livestock, fisheries and organic red sugar and coffee. Wonoharjo village has potential in agriculture so that it makes the village achievers for independent food security, so that it can be further developed 
into entrepreneurship in the field of agriculture based food security to be an agrotourism and edutourism area for economic strength for community income sources.

Therefore, that very interesting and important to research in these two locations that have the potential and prospects for the development of food security to support and develop agrotourism and edutourism, especially Wonoharjo village can adopt the success of Serang village in the field of local food security, agrotourism and edutourism. Then Serang village can partner with Wonoharjo village in the field of entrepreneurship in organic brown sugar which has become an export commodity.

\subsection{Agrotourism Base on Local Wisdom and Food Security for Edutourism Development}

The characteristics of Natural resources, environment, and people's productivity become a distinctive character, uniqueness, and attraction for visitors or tourists that Serang as a tourism village is categorized into agro-tourism village. Serang village names its agro-tourism with Lembah Asri initiated with the establishment of a temporary rest area or transit as passed by an alternative strategic road between Banyumas and Purbalingga heading to the Pemalang and Tegal. The next agro-tourism development in Serang village is to provide Community Service, education and training, outbound, skill-based games, camping, farming practices and researches from governmental and non-governmental institutions, universities and community development bodies. The available facilities in Serang village include flower gardens, playgrounds, labyrinths, camping sites, outbound and home stay activities, trekking, agro-kids, atv bike, high rope, picking up strawberries, flying fox, and horse riding. Parma $(2014,391)$ states that the potentials owned by the agro-tourism village community are highly dependent on its natural beauty and socio-cultural modality. Gunawan $(2016,166)$ also explains that agro-tourism is a business sector which organizes natural beauty and its uniqueness, agricultural productivity and its uniqueness, as well as offered activities, such as the distinctive arts and cultural potentials.

While the potential of Wonoharjo village has the main commodity, namely coconut to produce powdered brown sugar. The entrepreneurship group which is the center of organic red sugar production is the Nira Raharja group that receives coconut and brown sugar from other groups with a process of coaching and mentoring to complies with export standards. Coconut plantation area of 815 hectares produces 656 tons in 2018. Other food security potentials are rice commodities with a land area of 210 hectares which produces 1197 tons, 21 hectares of corn plants produce 86 tons, soybean plants with an area of 15 hectares with a yield of 23.4 tons , 9 hectares of green beans produce 7.2 tons, 32 hectares of cassava yields 480 tons. Then the livestock sector has as many as 3,914 goats and 28 cows. The superior and typical potential commodities that can be developed in addition to brown sugar are clove oil which can produce oil 1.7-2 tons of clove oil can be used and utilized in the health sector. The potential in the field of food security and livestock can support the conceptual plan of Wonoharjo Village in the tourism sector, especially agrotourism. Wonoharjo village has a natural tourist location called Bukit Dewa in the Mahameru mountains with a height of 600 meters, natural scenery that can be used as an outbound place, camping, and spot photos. Other tourist locations are resting places and food stalls called the Lemungsur Joglo which can be visited before or after the location of Bukit Dewa. Joglo Lemungsur is a village culinary place that provides rural specialties and coffee shops, homestays and training activities.

The location of Serang village and Wonoharjo village in addition to having similar achievements in food security that have the potential to support the development of agrotourism and educational tourism (edutourism) areas, also both have local wisdom. Serang people have several local wisdom: (1) habitual activities to plant horticultural plants from generation to generation as a way to maintain local food security in around the yard to fulfil the family needs and highly qualified commodities for commercial purposes as a form of mutual businesses; (2) decision making processes are always made through the discussion between the community and head of the village to mutually agree and decide the highly qualified commodities of horticultural plants collectively and commercially; (3) People are well united to cooperate each other with less competition as the highly qualified horticultural plants are determined, planting processes, cultivation, harvests, and selling are mutually made through discussions. Profits and losses are also mutually imposed on that there will be no group may individually obtain profits or losses as well described by the Javanese local wisdom "Tuna Satak Bathi Sanak" meaning that it is alright to have a little loss as long as the unity is well maintained; (4) having trusted brotherhood bond and mutual relationship for a long time between people and middlemen to make transactions on the yields of the horticultural commodities. Thus, people do not open or provide new access to market the horticultural products since they do not want to break their good relationship with the middlemen; (5) people involved in the farming association have a voluntary fund as they daily collect Rp. 2.000 and consider it as a mutual saving and is used to help others when losses occur or the harvests fail as well as for social and community activities. 
The local wisdom of Wonoharjo village is (1) The community has its own initiative, self-help by optimizing their land and capital, and self-management to develop agricultural, plantation and livestock land in a participatory manner. (2) Strong kinship in the community so that business competition between farmer groups and business groups does not occur because it is incorporated into one group which becomes the main activity and forum for deliberation to discuss problems and solutions as well as joint programs. (3) Community leaders, farmer groups and business groups with local government have a commitment to advance the village with social capital such as togetherness, mutual cooperation and solidarity.

Local wisdom is principal and certain ways believed, understood, and implemented by local people to make interactions with the environment and formulated in the forms of value system and customary norms. Zulkarnain et al. $(2008,72)$ states that local wisdom is a world view, knowledge and life strategy manifested in the form of activities carried out by local communities in answering various problems, fulfilling all elements of life needs to maintain, improve, and develop both surrounding human resources and natural resources (Suparmini et al., 2013, 11). Local wisdom is considered as people's commitment to uphold the good values to preserve and develop the ancestor heritage (Ridwan et al., 2016, 9).

There are important things and can be an example from Serang village, Purbalingga regency to be adopted by Wonoharjo village, Kebumen regency, namely: (1) Maintaining the tradition to grow the horticultural plants in the yard to fulfil people's daily needs, or in larger commercial yard, besides as a profession, it is also considered as local wisdom which becomes the distinctive characteristic and attraction to support the development of agrotourism. Local food security through planting the horticultural commodities around the house yard may even become the solution in dealing with the monetary crisis, staple food and oil price increase that those may not significantly influence people's life in Serang village.

(2) Uniqueness, beautiful and lovely natural resource supports, local wisdom, and food security, such as typical horticultural products make Serang village attractive not only as agro-tourism areas but also as edutourism or educational and tourism areas. Edutourism is an area with various potentials and tourism area covering natural beauty and environment with distinctive social communities and economic products produced to become a place for the development of knowledge, insight, and character building as a form of education, training, study, research and practice. Edutourism provides educational methods to identify, analyze, explore and construct factual reality directly to natural objects, communities' socio-cultures and social, decision-making process, community institutions, local wisdom, economic and production processes in agriculture, plantation, fisheries, and trade, as well as innovation adoption.

(3) Serang village as agrotourism and edutourism area frequently used as a place to hold various educational and training programs with various activities, such as outbound, camping, research program and scientific visit for research, practice and Community Service by the university students. Serang village is also considered as a place for various empowerment programs, such as counseling and training programs from central government, local government, universities, and non-government organizations with four to five activities a year. According to Hidayat $(201,36)$ tourism planning strategy may analyze the 'customer care ' training programs for local companies to hold joined trainings with others with various activities, such as sightseeing, camping, research, education and training, as well loving the natural beauty and recreation. Ridwan et al., $(2016,10)$ states that a local wisdombased tourist area not only offers and depends on natural beauty and local cultures, but is also utilized as a source of learning materials with outdoor learning methods.

The empowerment program is provided in the form of pest control, development of agricultural production, innovation adoption and diffusion programs, such as hydroponic techniques, planting engineering to anticipate extreme weather changes by providing greenhouses, highly qualified strawberry seeding commodities, and organic fertilizer making and crop yield storage within a large-capacity cooling machine. In addition, post-harvest programs, such as processing and packing for strawberries made into syrup and strawberry leaf tea, dodol and getuk. However, the horticultural products as local food security become superior commodities with unique characteristics, not yet maximally used as products which may be commercially sold to the visitors. Facilities that the horticultural products offer to visitors include directly picking the strawberries in the garden, while the other types of vegetable products are commercialized in Agrimart, a mini market selling fresh vegetables and fruit with sophisticated packaging with a plastic machine vacuum sealer. Similarly, the processed food and beverage products resulted from post-harvest yields may provide the farmers added value, while the production is not yet sustainable that the typical food is not always available at any time to enjoy directly and to become souvenirs for the tourists. 
Superior horticultural products as the typical and unique food security to develop agro-tourism areas in Serang village and Wonoharjo village have not maximally utilized due to: (1) The yields of horticultural products especially strawberry in Serang village and and brown sugar products in Wonoharjo village are directly sold to the middlemen, since a brotherhood bond has already been established for years and considered as tradition to directly earn the profits from the middlemen rather than processing them into food or beverages which require longer time to sell the products, especially to the visitors. The transactions made with the middlemen may gain several advantages, such as the yields are easily sold, no transportation cost, no risks dealing with the distance crops distribution since the yields are directly taken by the middlemen. Helping each other is bound between farmers and middlemen as they may provide loans either for seedling, fertilizer, or others as their business capital. According to the study conducted by the Ministry of Trade $(2014,3)$, middlemen have in important role in determining the capital circulation; buying and selling activities and connecting services also known as brokers.

(2) Insufficient event distribution for beneficiaries from the implementation of empowerment programs due to the domination of some community worker groups who always receive the empowerment programs since the information and coordination to the community access is owned by the closely related groups and parties to the village government authority. Women do not have equal to participate in the decision and policy making processes in villages, harvest plans and empowerment programs. Peterman et al. $(2010,33)$ states that there is still discrimination or unequal gender in development that results in loss of income, low productivity and poor nutrition and increased poverty. According to Sulaiman et al., $(2015,371)$ women's poor participations in processes of decision are due to the institutional roles and program implementation in the society which is still dominated by men. Women are very busy to take care of the household activities and less confident to argue and think critically.

One important village development goal and policy is to make sure that there is women's participation in the development processes (Kakati \& Behera, 2014, 288; Dhak, 2014, 475). The involvement of various parties to participate is one important democratic characteristic in the development (Goidel et al., 2008, 801; Choi 2014, 18).

(3) Empowerment programs are frequently provided by various institutions, yet less sustainable and comprehensive, no activity monitoring and evaluation. It means that there are many counseling and training programs, yet not comprehensive, not integrated, no synchronization, and no audit result from the empowerment program organizer. Thus, each institution conducts partial empowerment based on its interest, lack of outcome evaluation, no good cooperation, lack of mentoring activities, and poor institutional partnership. The village government only pays little attention to the sustainability of empowerment programs that when a certain party offers and holds the empowerment programs, it is not prior to the evaluation but continuing the previous one. The parties providing the empowerment programs could be to identify and evaluate the implementation of development programs given to the other parties and are expected to be able to make coordination and synergy with those have already completed the empowerment programs. According to Budi et al. (2013, 870), a program implementation in society is still poorly appreciated by the participants due to their lack of awareness that the realization of program achievement has less optimum result. Dewi et al. $(2013,131)$, explains that it is important to accelerate the development of tourism village by the involvement of all stakeholders to have a strategic role in the development of tourism village and are expected to provide participation in improving local community competences for the sake of local people empowerment.

(4) The inhibiting factors regarding to the development of agro-tourism, especially for the post-harvest commodities, such as typical food and beverages from Serang village include no culinary centers, or traditional food stalls, restaurants and agribusiness market (agrimarts). Thus, partnership is required to attract investments in developing good infrastructure, such as wider and better road access to the location and, culinary centers, agrimarts and typical restaurants derived from the food security. According to Parma $(2014,390)$, the problems arising at agro-tourism deal with village rules, village social institution and culture management, village size and land ownership, capital system, resource utilization, and selling system. Saputra et al. $(2016,507)$ states that agrotourism areas require supports in the development of road infrastructure and facilities, availability of visiting schedules and tourism package brochures.

\subsection{Community Empowerment Model in Development of Agrotourism and Edutourism}

The development of agro and edutourism in Serang village and Wonoharjo village has conducted through the community empowerment models as a series of systematic and comprehensive activities, such as planning, socialization, implementation, mentoring in the forms of comparative study, evaluation and monitoring, marketing and promotion strategies, as well as partnership and creating independence activities.

The basic concept of educational and tourism (edutourism) is development of agotourism which is used as the media and educational object to learn, increase knowledge, experience and skills to participate in processing and 
preserving the potential for natural wealth and beauty, horticulture farming, food security, postharvest food and beverage products, livestock, rural situations with unique social and cultural life as local wisdom.

So that in making edutourism require actors of empowerment from various parties who work together and collaborate between academics, local governments, the private sector and Non Governmental Organizations (NGOs) to design and implement edutourism programs as well as train and form administrators, instructors and facilitators of tourism from the local community. Then the instructor and facilitator to visitors and private parties who have an interest in increasing knowledge and ability to become entrepreneurs. So there needs to be training for the local community to become instructors or facilitators to conduct counseling and training such as horticulture planting processes, managing food security at home, making food and drinks based on food security, training with outbound methods.

The purpose of edutourism is to make tourism locations as well as locations for education, training and work practices especially regarding the process of agricultural, food security, local wisdom, creating caring and nature conservation for all groups ranging from elementary school children to tertiary institutions, private institutions, and social institutions. In the future, the development of agrotourism and edutourism can be managed by community groups themselves as instructors and assistants to visitors who have the desire to travel while drawing on experience and skills in food security, agriculture and processing of crops.

So in designing and implementing the concept of edutourism as the development of agrotourism with the stages of action namely planning stage, introductory study is conducted to discuss (1) Literature reviews from the research results, scientific journals, cases in mass media. (2) Opening access to the empowerment locations to permit the activity, introduction, and approach, required data collection by conducting interviews with the key informants, such as the village head, Village Consultation Body (BPD), farmer group leaders, as well as community and farmer institutions, business group, and agrotourism managers. Observation and documentation analyses are then conducted. (3) The results of literature studies and access opening are processed and analyzed deeper and sharper in discussion and Participatory Decision Making (PDM) activities by involving practitioners, experts, as well as agency and institutional actors implementing the community empowerment, especially in the same areas as the activity locations' focus to well design the making of program planning and the determination of community empowerment method in accordance with the identification and problem analysis, comprehensive and sustainable potentials and prospects, especially from the previously implemented community empowerment program. (4) Establishing community entrepreneurship empowerment programs based on food security and local wisdom to comprehensively and sustainably develop agrotourism and edutourism. According to Ulfah et al. (2017, 50), sustainable development may fulfill the present needs without eliminating the future generations' competence to fulfill the specified needs through the ecological, economic and social sustainability. Mulyadi (2015, v) explains that one important aspect of sustainable development emphasizes on a participatory process, that is, a policy established not only by the technocrats or policymakers, yet emphasizing on the communities' important roles. The sustainable development paradigms cover social, environmental, and people-centered development.

The next stage is socialization and agreement on the implementation of entrepreneurship empowerment programs by involving the community empowerment actors or beneficiaries - business groups, farmer groups and female farmer groups, managers of Village-Owned Enterprise and agrotourism. The results of empowerment programs are generated from the preliminary studies, agreement of time and activity programs as a form of participatory empowerment regarding to the conditions, needs, potentials, and community full engagement.

The agreement made with the entrepreneur groups is determining the empowerment time and programs. The implementation of entrepreneurship empowerment activities is conducted by counseling based on the identification and analysis of problems as well as the dialogical, participatory and evaluative potentials. The counseling is to motivate those engaged in the empowerment programs work harder, well cooperate, improve their knowledge and insights, and continue the empowerment programs. The next stage is conducting training simulation and implementation by inviting practitioners and experts in accordance with the well-given training activities. Business group and farmer group training is considered as training of trainer. It means that groups knowledgeable with skills and expertise obtained from the research results as community worker to become the facilitators for the formation and development of other groups.

The next community empowerment activity is mentoring the business groups and farmer groups already given the counseling and training, while conducting the evaluation and monitoring either in the form of developing or strengthening individuals, groups, institutions, processes and productions. Mentoring activities may be dialogically and in participative manners conducted through various forums of discussion, dissemination, questionnaire for assessment, personal interview and observation. 
Mentoring, monitoring, and evaluation are the new findings to follow up whether it is necessary to provide counseling and training (treatment program) either to the groups already or not yet joining the empowerment programs. Institutional improvement and strengthening may also be conducted through a comparative study by visiting the successfully developed village considered as as the role model. If the training is successful in product quantity and quality, the mentoring activities should be conducted for promotion and marketing strategies, such as counseling, packaging training, labeling, permit and certification to market the products from the health department and MUI Halal certificate in accordance with the development purposes, especially for human. According to Wardhani $(2009,53)$, a transformation may be achieved regarding to the values focusing on human and the potentials offered by the advance technology which is based on information. People should be considered as communities as the main focus or the main sources of development.

A community-centered development is characterized by the participations starting from the processes of development planning, budgeting, implementation and evaluation. According to Levine et al. (2005), there are various discussions involving the mostly motivated communities to make voluntary participations. Reed et al. (2009: 1934) states that social phenomena are influenced by the identification of individuals, groups and organizations involved in the process of decision making and action.

The village participation involvement in planning, organizing, budgeting and evaluation stages is considered less active in the discussions (Bancin 2011, 179; Carcasson et al., 2010, 37). A discussion is ideally utilized as a communication forum for the development and empowerment to change those less active villagers to become more active to participate (Gastil \& Black 2008, 2; Nabatchi 2010, 377). Discussion is one active participation of a community. Community's participation is required in planning and determining the policies as well as making the decisions. Participation process involves communities dealing with the problems, situations, conditions, potentials, and needs in each development stage by mutually formulating a number of values and systems to understand (Hawkins \& Wang 2011, 27).

The next community empowerment implementation stage is product marketing supported by the promotion strategies through social mediaand internet access which is utilized by more people, such as website, Facebook, and Instagram as well as television, newspaper, brochure, banner and billboard in strategic areas to be easily accessed by the public. Entrepreneurship product promotion media may be created by conducting trainings of marketing and promotion strategies to the community groups, especially trainings intended to make the promotion media for marketers and public relation officers by utilizing the internet technology media. The other form of promotion media is art and culture festival performance on Mount Selamet which has already become an annual routine agenda involving people's participations in four districts around Mount Selamet and attended by all related stakeholders.

The role of public relation is greatly required in promoting the entrepreneurship products to establish a mutually relationship that the public may later accept and acknowledge the existence of the products (Yulianita, 2004, 194). Marketing is planning processes and design implementation as well as pricing, promotion and distribution of ideas dealing with goods or services to create exchanges in meeting the individual and organizational goals (Rosyad, 2011, 214). Promotion is one marketing element intended to inform, persuade, and establish perceptions on customers' needs, as well as to create the product image that attract the costumers to buy the product (Wahyuningtyas 2013, 121). Wening et al. $(2014,7)$ states that the power of promotion and marketing are indicated by the product quality, customer service, offered facilities, tourism variation, company location, promotion effectiveness, and capital. According to Wardhana and Pradana $(2016,29)$, there is a promotion and marketing strategy called Viral Marketing Online Shop consisting of customer recommendation factor, newsletter, and social media relationship with community, free offers, list of customers, discussion rooms, list of reference, description of products, affiliate programs, and internet search engines in online business.

The next stage is mentoring to establish partnership and investment in the development of agrotourism and edutourism with the government, private sectors, and universities. All parties such as business groups, farmer groups and agrotourism managers should be proactive to establish and expand the communication networks. According to Castells $(2007,238)$ and Cho $(2014,283)$ the formation of communities in digital era to expand networking has an important role in providing information, knowledge, and marketing networks for wider communities.

Partnerships are beneficial in increasing the quantity and quality of products and marketing, such as the provision of agricultural production facilities and infrastructure (Sarana dan prasarana produksi/Saprodi) such as seed, fertilizer, agricultural medicine, agricultural devices and equipment, the provision of machine devices for packaging and product labeling as well as the construction of agrimarts and greenhouses. 
Tourism facilities, outbound, camping sites, games, lodging, food stalls or restaurants, as well as road infrastructure should also be developed and added. Based on the Government Regulation No. 44/1997 on partnership, Article 1 states that partnership is business cooperation between small business groups with medium business groups and large business groups with counseling and development by the medium and/or bigger business by considering the mutual principles regarding to needs, supports, and benefits.

Sustainable development through business partnership may guarantee the creation of efficiency, growth, justice, even distribution, and environmental awareness supported by the institutional consolidation, either at the level of farmers, private sectors, or government (Saptana \& Ashari, 2007, 129). The foundation of sustainable development surely provides a participation space, concerning on potentials and satisfaction of the society to meet the development goals (Mahdavinejad \& Amini 2011, 406; Sylvia et al., 2014, 234).

According Sulistyo and Adiatama (2011,25), partnership program aims at improving the ability of small business which is supported by the capital aspects and Human Resources (HR) training to become more professional and competence to support the promotion and bussiness marketing sustainability. Rahmatullah $(2012,36)$ states that there are three basic partnership principles covering equality or balance of rights and obligations, transparency, and mutual benefit between companies, government, managers and recipients of Corporate Social Responsibility (CSR).

The last empowerment program stage is the independence availability of individual, group and institution of farming communities that there is no dependency on the sustainable external empowerment programs. Independency may become the role model, empowerment motivator, or actor for the other regions to mutually develop, improve and prosper the communities. To realize the mentoring program in partnership and independence, the strategies by Setiawan et al. $(2015,417)$ are conducted to improve the practical ability of younger generations in doing agro-business to become more adaptive and well prepared, to increase the ecological innovations in agrobusiness to offer more business alternatives and to develop the competitive markets. According to Dumasari and Waremin $(2013,205)$, the development of independence and entrepreneurship competence as well as adopting the advanced technology for farmers may not be separated from the responses and supports of the local resources around the village. Widjajanti $(2011,15-16)$ states that the empowerment results are considered to have the similar purposes with the independence of communities to form individuals and communities to become more mature in thinking, acting and controlling their activities. Sumardjo and Firmansyah $(2015,18)$ affirm that the purpose of mentoring program is to design the community development in participative manners and effectively mobilize the local resources, organize communities and their creativity in accordance with the potential characteristics to support the independence of communities through productive efforts which are proven effective to create and develop new innovations and practices resulted by the communities. Sidik $(2015,119)$ affirms that independence is an effort made by the local communities through village government institutional capacity and community empowerment to collectively utilize the village's ability, initiative and movement in developing the potential sources of both physical and nonphysical local assets as a tourist village.

Based on community empowerment stages, especially in development of agrotourism and edutourism based on food security \& local wisdom, the design is illustrated in Figure 1 as follows. 


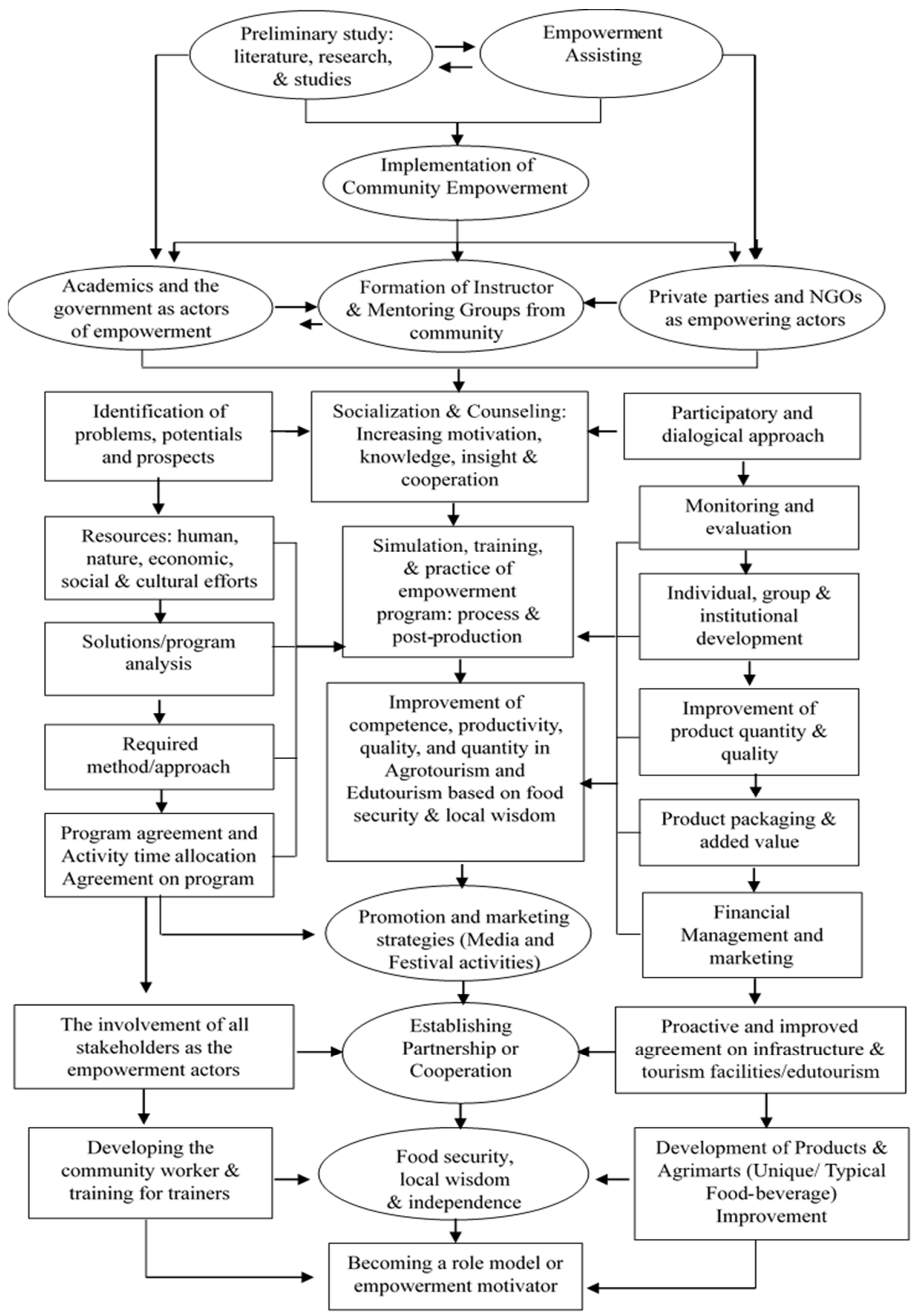

Figure 1. Community Empowerment of Agroturism and Edutourism Development 


\section{Conclusion}

Serang village and Wonoharjo village could be made as one tourism village has the potentials, characteristics, and uniqueness as a lovely and cool mountainous area with its local wisdom, horticultural food security providing various tourism excitements and facilities.

Serang village and Wonoharjo village are not only an agro-tourism area but may also be used as an educational location, since it is often used as an location for educational and training activities, researches, practicum, social services, and community services, out bond and camping activities for university, government and private institutions.

Educational tourism called edutourism have utilize and provide educational media from tourism potentials based on natural desires, food security, economic products such as village food and beverages, and local wisdom.

The purpose of edutourism is to make tourism locations as well as locations for education, training and work practices especially regarding process of agricultural, food security, creating caring and nature conservation for all groups ranging from elementary school children to tertiary institutions, private institutions, and social institutions.

The development of agrotourism and edutourism can be managed by community groups themselves as instructors and assistants to visitors who have the desire to travel while drawing on experience and skills in food security, agriculture and processing of crops.

The Community empowerment programs to developing of agrotourism and edutourism have been implemented in the counseling and training, yet less maximum on mentoring stage for the development of institutions, pest control. Furthermore, the results of post-harvest entrepreneurial empowerment the forms of unsustainable food and beverage products made of strawberries in Serang village and coffee products and clove oil in Wonoharjo village.

The Community empowerment programs are greatly essential to be comprehensively and sustainably implemented and should be integrated starting from planning programs to the implementations, such as counseling, training, mentoring, monitoring, evaluation, promotion, marketing and partnership.

\section{Acknowledgments}

We would like to thank for Institute for Research and Community Service in University of Jenderal Soedirman who has provided his research program and The International Educational Research who published the results of this study. Thank you to the research informants and village government at the research location who have supported the research process.

\section{References}

Adi, I. R. (2013). Intervensi Komunitas dan Pengembangan Masyarakat: sebagai Upaya Pemberdayaan Masyarakat. Jakarta: Rajawali Pers.

Ashari., Saptana., \& Purwantini, T. B. (2012). Potensi dan Prospek Pemanfaatan Lahan Pekarangan untuk Mendukung Ketahanan Pangan. Forum Penelitian Agro Ekonomi, 30(1), 13-30. https://doi.org/10.21082/fae.v30n1.2012.13-30

Bancin, M. H. (2011). Peningkatan Partisipasi Masyarakat dalam Program Nasional Pemberdayaan Masyarakat (PNPM) Mandiri Perdesaan (Studi Kasus: Bandung Barat). Jurnal Perencanaan Wilayah dan Kota, 22(3), 179-194.

Basundoro, P. (2001). Industrialisasi, Perkembangan Kota, dan Respons Masyarakat: Studi Kasus Kota Gersik. Humaniora, 8(2), 133-140. https://doi.org/10.22146/jh.v13i2.719

Budi, N. D. A., Soeaidy, M. S., \& Hadi, M. (2013). Implementasi Proggram Pemberdayaan Masyarakat Melalui Peelatihan Keterampilan Dasar (Studi di Kecamatan Tambaksari Kota Surabaya). Jurnal Administrasi Publik (JAP), 1(5), 862-871.

Carcasson, M., Black, L.W., Sink., \& Elizabeth, S. (2010). Communication studies and deliberative democracy: Current contributions and future possibilities. Journal of Public Deliberation, 6(8), 1-38.

Castells, M. (2007). Communication, power and counter-power in the network society. International Journal of Communication, 1, 238-266.

Cho, J. (2014). Will social media use reduce relative deprivation? Systematic analysis of social capital's mediating effects of connecting social media use with relative deprivation. International Journal of Communication, 8 , 2811-2833.

Choi, I. (2014). What explains the success of participatory budgeting? Evidence from seoul autonomous districts. 
Journal of Public Deliberation, 10(9), 1-19.

Collins, P., Alger, M., Whitelaw, G., \& Williams, B. (2017). Implementing integrated community sustainability planning: a comparative case study of three mid-sized municipalities in Ontario, Canada. International Journal of Sustainable Development, 20(2),124-145. https://doi.org/10.1504/IJSD.2017.083486

Dewi, M.H.U., Fandeli, C., \& Baiquni, M. (2013). Pengembangan Desa Wisata Berbasis Partisipasi Masyarakat Lokal Di Desa Wisata Jatiluwih Kabupaten Tabanan, Bali. Kawistara, 3(2), 129-139. https://doi.org/10.22146/kawistara.3976

Dhak, B. (2014). Food security act, 2013: Oppurtunities and challenges for the Backward States in India. Journal of Rural Development, 33(4), 475-491.

Dumasari, \& Watemin. (2013). Karakteristik Sosial Ekonomi Petani Miskin dalam Pengelolaan Usaha Mikro “Tourism Souvenir Goods". Mimbar, 29(2), 205-214. https://doi.org/10.29313/mimbar.v29i2.398

Fakhrian, R., Hindersah H., \& Burhanudin H. (2015). Arahan Pengembangan Sabuk Hijau (Green Belt) di Kawasan Industri Kariangau (KIK) Kota Balikpapan. Prosiding, Penelitian SPeSTA, 15-20.

Gastil, J., \& Black, L. W. (2008). Public deliberation as the organizing principle of political communication research, Journal of Public Deliberation, 4(1), 1-47. https://doi.org/10.4135/9781483329208

Goidel, R. K., Freeman, C. M., Procopio, S., \& Zewe C. F. (2008). Who participates in the public square and does it matter?. Public Opinion Quarterly, 72(4), 792-803. https://doi.org/10.1093/poq/nfn043

Government Regulation No. 44/1997 on partnership.

Gunawan, I. M. (2016). Pengembangan Agrowisata untuk Kemandirian Ekonomi dan Pelestarian Budaya di Desa Kerta, Payangan Gianyar. Jumpa, 3(1), 156-174. https://doi.org/10.24843/JUMPA.2016.v03.i01.p11

Handoko, W., Sulaiman, A. I., \& Akbar, A. A. S. (2014). Komunikasi Partisipatif dalam Proses Pembagunan Bendungan Matenggeng Kabupaten Cilacap Jawa Tengah. Jurnal Penelitian Komunikasi, 17(2), 141-152. https://doi.org/10.20422/jpk.v17i2.13

Hawkins, C. V., \& Wang, X. (2011). Sustainable development governance: Citizen Participation and Support Networks in Local Sustainability Initiatives. Public Works Management Policy, 17(1), 7-29. https://doi.org/10.1177/1087724X11429045

Hidayat, M. (2011). Strategi Perencanaan dan Pengembagan Objek Wisata (Studi Kasus Pantai Pangandaran Kabupaten Ciamis Jawa Barat). Tourism and Hospitality Essentials (THE) Journal, 1(1), 1-33. https://doi.org/10.17509/thej.v1i1.1879

Irianta, F. X. G. (2008). Kajian Dampak Perkembangan Industri terhadap Kondisi Lahan di Kawasan Bawen Kabupaten Semarang. Tesis, Universitas Diponegoro.

Kakati, B. K., \& Behera, M. C. (2014). Women workers and their status in MGNREG programme: A study in Jharkhand. Journal of Rural Development, 33(3), 281-290.

Kenny, S. (1999). Developing Communities For The Future Development The Australia. Australia: Nelson Australia Prelimited.

Levine, P., Fung A., \& Gastil, J. (2005). Future directions for public deliberation. Journal of Public Deliberation, 1(3), 1-13.

Mahdavinejad, M., \& Amini, M. (2011). Public participation for sustainable urban planning in case of Iran. Procedia Engineering, International Conference on Green Buildings and Sustainable Cities, 21, 405-413. https://doi.org/10.1016/j.proeng.2011.11.2032

Mardikanto, T., \& Soebiato, P. (2012). Pemberdayaan Masyarakat dalam Perspektif Kebijakan Publik. Bandung: Alfabeta.

Mulyadi, M. (2015). Pembangunan: Analisis Kritis Upaya Meningkatkan Kualitas Hidup Manusia. Sali, S (Ed). Pembangunan Berkelanjutan: Dimensi Sosial, Ekonomi, dan Lingkungan. Jakarta: Pusat Pengkajian, Pengolahan Data dan Informasi (P3DI) Sekretariat Jenderal DPR RI dan Azza Grafika.

Nabatchi, T. (2010). Addressing the citizenship and democratic deficits: The potential of deliberative democracy for public administration. The American Review of Public Administration, 40(4), 376-399. https://doi.org/10.1177/0275074009356467

Novitasari, D. (2014). Analisis Kebijakan Terhadap Pengembangan Pariwisata Di Kecamatan Wonosalam 
Kabupaten Jombang. Kebijakan dan Manajemen Publik, 1(1), 1-8.

Nugroho, B. P., Karim, S., Sidik, A., Prihawantoro, S., \& Firmansyah, R. (2012). Penguatan Klaster Industri Agro di Kabupaten Malang. Laporan Akhir Badan Pengkajian dan Penerapan Teknologi. Jakarta: Kementerian Riset dan Teknologi.

Pamulardi, B. (2006). Pengembangan Agrowisata Berwawasan Lingkungan: Studi Kasus Desa Wisata Tingkir Salatiga. Tesis, Universitas Diponegoro.

Parma, P. G. (2014). Pengembangan Model Penguatan Lembaga Pertanian sebagai Prime Mover Pembangunan Kawasan Daerah Penyangga Pembangunan (DPP) Destinasi Wisata Kintamani Bali. Jurnal Ilmi Sosial dan Humaniora, 3(1), 380-393. https://doi.org/10.23887/jish-undiksha.v3i1.2928

Peterman, A., Behrman, J., \& Quisumbing, A. (2011). A Review of Empirical Evidence on Gender Differences in Nonland Agricultural Inputs, Technology, and Services in Developing Countries, United Nation: International Food Policy Research Institute.

Purwaningsih, Y. (2008). Ketahanan Pangan: Situasi, Permasalahan, Kebijakan dan Pemberdayaan Masyarakat. Jurnal Ekonomi Pembangunani, 9(1), 1-27. https://doi.org/10.23917/jep.v9i1.1028

Rahmatullah. (2012). Model Kemitraan Pemerintah dengan Perusahaan Dalam Mengelola CSR; Studi Kasus di Kota Cilegon. Informasi, 17(1), 36-47.

Reed, M. S., Graves, A., Dandy, N., Posthumus, H., Hubacek, K., Morris, J., Prell, C., Quinn, C. H., \& Stringer, L.C. (2009). Who's in and why? A typology of stakeholder analysis methods for natural resource management. Journal of Environmental Management, 90, 1933-1949. https://doi.org/10.1016/j.jenvman.2009.01.001

Ridwan, M., Fatchan A., \& Astina I. K. (2016). Potensi Objek Wisata Toraja Utara Berbasis Kearifan Lokal sebagai Sumber Materi Geografi Pariwsata. Jurnal Pendidikan, 1(1), 1-10. https://doi.org/10.17977/jp.v1i1.6601

Rosyad, U. N. (2011). Pengaruh Komunikasi Pemasaran terhadap Perluasan Pangsa Pasar. Mimbar, 27(2), 213224. https://doi.org/10.29313/mimbar.v27i2.330

Saliem, H. P. (2011). Kawasan Rumah Lestari (KRPL): Sebagai Solusi Pemantapan Katahanan Pangan. Makalah, disampaikan pada Kongres Ilmu Pengetahuan Nasional (KIPNAS), di Jakarta tanggal 8-10 November 2011, $1-10$.

Saptana., \& Ashari. (2007). Pembangunan Pertanian Berkelanjutan Melalui Kemitraan Usaha. Jurnal Litbang Pertanian, 26(4), 123-130.

Saputra, M. R. D., Dewi, R. K., \& Dewi N. P. K. (2016). Pola Subkontrak Kopi Luwak Satria Agrowisata di Desa Manukaya, Kecamatan Tampak Siring, Kabupaten Gianyar. E-Jurnal Agribisnis dan Agrowisata, 5(3), 498508.

Setiawan, I., Sumardjo., Satria A., \& Tjiptropranoto P. (2015). Strategi Pengembangan Kemandirian Pelaku Muda Agribisnis "Brain Gain Actors" di Jawa Barat. Mimbar, 31(2), 409-418. https://doi.org/10.29313/mimbar.v31i2.1491

Sidik, F. (2015). Menggali Potensi Lokal Mewujudkan Kemandirian Desa. Jurnal Kebijakan \& Administrasi Publik, 19(2), 115-131. https://doi.org/10.22146/jkap.7962

Sukandar, D. (2004). Model Ketahanan Pangan Tingkat Rumah Tangga pada Desa Holtikultur. Jurnal Teknologi dan Industri Pangan, 15(2), 165-170.

Sulaiman, A.I., Lubis D.P., Susanto, D., \& Purnaningsih, N. (2015). Komunikasi Stakeholder dalam Musyawarah Perencanaan Pembangunan (Musrenbang). $\quad$ Mimbar, $\quad 31(2), \quad 367-37$. https://doi.org/10.29313/mimbar.v31i2.1467

Sulaiman, A.I., Sugito, T., \& Sabiq, A. (2016). Komunikasi Pembangunan Partisipatif untuk Pemberdayaan Buruh Migran. Jurnal Ilmu Komunikasi, 13(2), 233-252. https://doi.org/10.24002/jik.v13i2.734

Sulystio H., \& Adiatama, A. 2011. Model Optimalisasi Kemitraan UKM dan BUMN Melalui Program PKBL Untuk Meningkatkan Kinerja UKM. Riptek. 5(2), 25-40.

Sumardjo., \& Firmansyah, A. (2015). Inovasi Pemberdayaan Masyarakat Berbasis Sumber Daya Pangan di Sekitar Wilayah Operasional PT. Pertamina Asset 3 Subang Field. Agrokreatif, 1(1), 8-19. https://doi.org/10.29244/agrokreatif.1.1.8-19

Sumardjo., \& Firmansyah, A. 2015. Inovasi Pemberdayaan Masyarakat Berbasis Sumber Daya Pangan di Sekitar Wilayah Operasional PT. Pertamina Asset 3 Subang Field. Agrokreatif, 1(1), 8-19. 
https://doi.org/10.29244/agrokreatif.1.1.8-19

Suparmini., Setyawati, S., \& Sumunar, D.R.S. (2013). Pelestarian Lingkungan Masyarakat Baduy Berbasis Kearifan Lokal. Jurnal Penelitian Humaniora, 18(1), 8-22.

Sylvia, A., Owiny, M. K., Audrey, N., \& Meretzki (2014). The use of social media technologies to create, preserve, and disseminate indigenous knowledge and skills to communities in east africa. International Journal of Communication, 8, 234-247.

Telesford, J. N., \& Strachan, P. A. (2017). Strategic Sustainability Procedures: Focusing Business Strategic Planning on the Socio-Ecological System in an Island Context. Sustainable Development, 25(1), 35-49. https://doi.org/10.1002/sd.1640

Ulfah, I. F., Setiawan, A., \& Rahmawati, A. (2017). Pembangunan Desa Berbasis Potensi Lokal Agrowisata di Desa Bumiaji, Kota Batu, Jawa Timur. Politik Indonesia: Indonesian Political Science Review. 2(1), 46-64. https://doi.org/10.15294/jpi.v2i1.8486

Wahyuningtyas, K. K. (2013). Strategi Promosi Pertamax PT. Pertamina UPMS VI Balikpapan dalam Meningkatkan Loyalitas Pelanggan. eJournal Ilmu Komunikasi, 1(4), 120-134.

Wardhana, A., \& Pradana, M. (2016). Viral Marketing Determinants of Top Online Shop Brands in Indonesia. Mimbar, 32(1), 25-30. https://doi.org/10.29313/mimbar.v32i1.1572

Wardhani, A. C. (2009). Pembangunan yang Berpusat Pada Manusia. Jurnal Pertumbuhan dan Perkembangan, 2(3), 47-54.

Wening, N., Al Hasni, M., \& Fitryana, R. (2014). Strategi Pemasaran untuk meningkatkan Jumlah Kunjungan pada Objek Wisata Kebun Raya dan Kebun Binatang (KRKB) Gembira Loka di Kota Yogyakarta. Jurnal Kajian Bisnis, 22(1), 1-10. https://doi.org/10.32477/jkb.v22i1.193

Widjajanti, K. (2011). Model Pemberdayaan Masyarakat. Jurnal Ekonomi Pembangunan, 12(1), 15-27. https://doi.org/10.23917/jep.v12i1.202

Yulianita, N. (2004). Etika dan Estetika Promosi pada aktivitas "PR" Perguruan Tinggi Swasta. Mimbar, 20(2), 194-218. https://doi.org/10.29313/mimbar.v20i2.136

Zulkarnain. (2009). Kearifan Lokal dalam Pemanfaatan dan Pelestarian Sumber Daya Pesisir (Studi Kasus di Desa Panglima Raja Kecamatan Concong Kabupaten Indragiri Hilir Propinsi Riau). Jurnal Terubuk, 37(2), 117132.

\section{Copyrights}

Copyright for this article is retained by the author(s), with first publication rights granted to the journal.

This is an open-access article distributed under the terms and conditions of the Creative Commons Attribution license (http://creativecommons.org/licenses/by/4.0/). 